\title{
PARA SERVIR A DEUS E À NAÇÃO: A RECEPÇÃO DA MÚSICA RELIGIOSA DE JOSÉ MAURÍCIO NUNES GARCIA NO PANORAMA DA RESTAURAÇÃO MUSICAL CATÓLICA NO BRASIL
}

\author{
Fernando Lacerda Simões Duarte \\ PPGArtes/UFPA
}

\section{Resumo}

Este artigo analisa a recepção da música religiosa do padre José Maurício Nunes Garcia (1767-1830) no panorama da Restauração Musical Católica no Brasil. Considerado por críticos e por parte da historiografia um mito fundador da brasilidade na música, a difusão de sua obra serviu a distintos interesses ou compreensões da identidade nacional. A restauração musical se baseava em rígidas normas, sistematizadas por Pio X num motu proprio promulgado em 1903. Este documento pressupunha uma noção de universalidade fundada em referenciais culturais europeus. Questiona-se aqui que tratamento foi dispensado pela Igreja à memória musical legada por José Maurício, como os restauristas lidaram com as influências da ópera em sua obra sacra, bem como os interesses nacionais ou religiosos envolvidos em sua aceitação. Os dados foram analisados a partir dos referenciais de memória e identidade, e apontam para uma equiparação cultural com a Europa como principal argumento para a aceitação, ainda que de maneira negociada em alguns aspectos musicais.

\section{Palavras-chave:}

Música religiosa - Igreja Católica; Memória, identidade e música; Motu proprio "Tra le Sollecitudini"; Música colonial brasileira.

\section{INTRODUÇÃO}

A relação dos sujeitos com o passado não ocorre de forma absolutamente objetiva. Isto porque a história se faz de passado, mas também do presente, sendo-Ihe inescapável o condicionamento a este último. Assim, toda história tem algo de contemporâneo (LE GOFF, 1990, p. 51). Igualmente condicionada pelo presente, a memória é “uma reconstrução continuamente atualizada do passado, mais que uma reconstituição fiel do mesmo" (CANDAU, 2011, p. 9). Este processo vivo de reconstrução

\section{Abstract}

This article analyzes the reception of the religious music by the priest José Maurício Nunes Garcia (1767-1830) in the panorama of the Catholic musical Restoration in Brazil. Regarded by critics and by a part of the historiography as a founding myth of the Brazilianness in music, the diffusion of his work served to different interests or understandings of the national identity. The musical Restoration was based on strict standards, systematized by Pius $X$ in a motu proprio promulgated in 1903. This document presupposed a notion of universality based on European cultural references. It is questioned here what treatment the Church gave to the musical memory of José Maurício, how the restorers dealt with the influences of the opera in its sacred work, as well as the national or religious interests involved in its acceptance. The data were analyzed from the references of memory and identity, and point to a cultural equation with Europe as the main argument for acceptance, albeit in a negotiated way in some musical aspects.

Keywords:

Religious music - Catholic Church; Memory, identity and music; Motu proprio "Tra le Sollecitudini"; Brazilian colonial music.

do passado parte de necessidades dos indivíduos no presente e se dá individual e coletivamente, atuando de maneira direta na construção de identidades. Apesar de a história alimentar a memória (LE GOFF, 1990, p. 447), Pierre Nora as diferenciou principalmente no tocante à fluidez desta última:

Memória, história: longe de serem sinônimos, tomamos consciência que tudo opõe uma à outra. A memória é a vida, sempre carregada por grupos vivos e, nesse sentido, ela está em permanente evolução, aberta à dialética da lembrança e do esquecimento, inconsciente 
de suas deformações sucessivas, vulnerável a todos os usos e manipulações, suscetível de longas latências e de repentinas revitalizações. A história é a reconstrução sempre problemática e incompleta do que não existe mais. A memória é um fenômeno sempre atual, um elo vivido entre o passado e o presente; a história, uma representação do passado. Porque é afetiva e mágica, a memória não se acomoda a detalhes que a confortam; ela se alimenta de lembranças vagas, telescópicas, globais ou flutuantes, particulares ou simbólicas, sensível a todas as transferências, cenas, censuras ou projeções. A história, porque operação intelectual e laicizante, demanda análise e discurso crítico. A memória instala a lembrança no sagrado, a história a liberta, e a torna sempre prosaica. A memória emerge de um grupo que ela une, o que quer dizer, como Halbwachs o fez, que há tantas memórias quanto grupos existem; que ela é, por natureza, múltipla e desacelerada, coletiva, plural e individualizada. A história, ao contrário, pertence a todos e a ninguém, o que Ihe dá uma vocação para o universal. A memória se enraíza no concreto, no espaço, na imagem, no objeto. (NORA, 1993, p. 9).

O fato de a história pertencer a todos e a ninguém (LE GOFF, 1990) não significa que a historiografia seja isenta de interesses ou hierarquizações. O pouco ou quase nenhum destaque dado à música ritual em grande parte dos manuais de história da música ocidental a partir do século XVIII sinaliza para interesses específicos: os teatros, a ópera e as orquestras sinfônicas foram mais valorizados pela sociedade industrial do que a música religiosa (CASTAGNA, 2000, p. 84). É possível afirmar que a música dos teatros integra, em certa medida, a identidade coletiva na Era Industrial. Segundo Paul Marie Veyne (apud CANDAU, 2011, p. 136), "o historiador pode escrever duas linhas sobre dez anos. O leitor terá confiança, pois presumirá que esses dez anos são vazios de acontecimentos". Neste sentido, o pouco destaque conferido a uma determinada prática musical não significa que esta tenha deixado de existir, mas revela hierarquizações de interesses. Além disto, processos de canonização de determinados gêneros ou compositores implicam esquecimentos. Desta maneira, a crítica musical e os historiadores da música têm atuação direta na produção de esquecimentos (VILELA, 2010).

Este trabalho tem como objeto a recepção da obra de um compositor canônico na historiografia da música brasileira entre 1903 e 1963, período em que as práticas musicais religiosas tiveram pouco destaque na historiografia da música no Brasil. O compositor é o padre José Maurício Nunes Garcia (1767-1830), que ocupa certamente a posição mais elevada no panteão dos compositores coloniais brasileiros. Se sua obra musical foi tema de diversos estudos na fase científica da musicologia no Brasil $^{1}$, em uma fase literária anterior - mais próxima das biografias do que das fontes musicais -, o padre mulato já tinha seu valor reconhecido como ícone de brasilidade na música colonial. Este reconhecimento obedecia ao interesse de se construir uma identidade nacional, conforme se verá ao longo deste artigo.

O período em que se estuda a recepção da obra musical religiosa de José Maurício é o da chamada Restauração Musical Católica, que foi oficializada com a promulgação do motu proprio "Tra le Sollecitudini" sobre música sacra de Pio $X$, em 1903. Este documento buscava cercear, dentre outras coisas, a execução de música sacra de características teatrais, ou seja, o repertório cujas características se aproximassem da ópera ou da música sinfônica. O resultado desta proibição seria o inevitável esquecimento de grande parte da música religiosa produzida no Brasil nos séculos XVIII e XIX. Este esquecimento se estendeu inclusive às fontes musicais, sobretudo, no Rio de Janeiro: na comparação entre catálogos de fontes musicais provenientes da Capela Imperial elaborados em 1902 e 1922, Cleofe Person de Mattos constatou a destruição de parte considerável do acervo. A razão deste fato parece residir na inadequação do repertório às metas musicais então vigentes no sistema religioso católico:

A esta inadequação se referiu Frei Pedro Sinzig (1876-1952) quando afirmou que "excetuando muitas composições do Padre José Maurício, a maior parte das obras [recolhidas ao Arquivo do Cabido Metropolitano] não corresponde às normas dadas pela Igreja Católica para a música sacra". A observação precede uma transcrição abreviada do catálogo de 1922, pioneiramente incluída no pouco conhecido Dicionário Musical de Frei Sinzig, publicado em 1947. Neste léxico consta também o importante testemunho de que o acervo era "quase nunca procurado", apontando para o estado incipiente da atividade musicológica de então, ao menos no que diz respeito ao estudo de fontes primárias (HAZAN, [20--]). 
Frei Pedro Sinzig foi um dos protagonistas no processo de implantação dos princípios do motu proprio no Brasil, tendo atuado como compositor, organista, regente de coros, mas também, na década de 1940, como editor do periódico Música Sacra - o de maior difusão no Brasil sobre este tema - e censor na Comissão Arquidiocesana de Música Sacra do Rio de Janeiro. Esta comissão publicava suas decisões nas sessões Livro de Ouro da Música Sacra e Obras recusadas do periódico editado por Sinzig, e chegou a ter um index, o $1^{0}$ Índice das Músicas Examinadas para uso litúrgico pela Comissão Arquidiocesana de Música Sacra do Rio de Janeiro (CAMS-RJ, 1946a).

O virtuosismo vocal e, na maior parte, o acompanhamento orquestral figurado foram os principais itens que serviam de justificativa para a recusa de obras para o uso na liturgia. 0 acompanhamento ideal deveria ter caráter vocal, de simples sustentação ao canto, sem qualquer tipo de figuração. Ao contrário da rigidez com que as obras de diversos compositores foram tratadas em relação a quesito, exceções e adequações foram feitas às composições de José Maurício. Diante desta aparente incongruência, foram formulados os seguintes problemas: que tratamento foi dispensado à memória musical legada pela obra musical religiosa de José Maurício Nunes Garcia durante a Restauração Musical Católica no Brasil? É possível falar em isonomia em relação àquele dado às obras de outros compositores coloniais? A que interesses serviu a aceitação da música sacra de José Maurício para o uso litúrgico após a promulgação do motu proprio de Pio X? A fim de responder a tais questões, recorreu-se à pesquisa bibliográfica e documental, inclusive a fontes musicais que se encontram recolhidas a acervos de diferentes regiões do Brasil ${ }^{2}$. Somam-se aos referenciais teóricos relativos à memória e ao esquecimento já apresentados, uma abordagem da Igreja Católica enquanto sistema social, nas perspectivas de Walter Buckley e Niklas Luhmann, apresentadas mais adiante. Análises necessárias para a abordagem da construção da identidade nacional foram buscadas em fontes secundárias.

O trabalho foi estruturado em quatro partes: uma visão abrangente da Restauração Musical Católica e seus desdobramentos no Brasil, a construção da identidade nacional e seus reflexos na música, a recepção da obra musical religiosa de José Maurício Nunes Garcia durante a Restauração Musical Católica e um olhar para o presente.

\section{A RESTAURAÇÃO MUSICAL CATÓLICA NO BRASIL}

Dois movimentos desencadeados na Europa durante o século XIX serviram de base para a Restauração Musical Católica: o Cecilianismo e a paleografia musical de Solesmes. Na abadia beneditina de São Pedro de Solesmes se desenvolveu o estudo semiológico do ritmo e da notação gregorianos, que também acabou por estabelecer um modelo de interpretação hegemônico até o presente. Passível de críticas por tentar estabelecer um modelo arqueológico, diverso do canto legado pela tradição, fato é que o movimento de Solesmes impactou profundamente o cenário musical europeu da segunda metade do século XIX e a música litúrgica católica: do caráter modal nas obras de Debussy, Ravel, Saint-Saëns, D'Indy e Fauré (IGAYARA, 2001, p. 40) à atuação da École de Chant Lithurgique et de Musique Religieuse (Schola cantorum de Paris), responsável pelo "desenvolvimento de uma nova música litúrgica para órgão baseada na substância melódica e na modalidade do cantochão restaurado" (GOLDBERG, 2004, p. 149).

O estabelecimento de bases científicas para a restauração da música católica não foi, entretanto, exclusividade de Solesmes. A Academia de Santa Cecília da Alemanha (Cäcilien Vereins) e agremiações congêneres que se espalharam pela Europa e América foram integradas por acadêmicos e especialistas em música litúrgica. Este movimento conhecido como Cecilianismo tinha como uma de suas bases à condenação à influência da música teatral na liturgia. Mais do que restaurar modelos do passado, pretendiase restaurar a música litúrgica a uma suposta condição de dignidade perdida ${ }^{3}$. Em outras palavras, a Restauração Musical Católica tinha em sua base uma representação de decadência, que se devia a uma espécie de contaminação da música litúrgica pela música dos teatros, conforme evidenciou o motu proprio de Pio X:

Tal é o abuso em matéria de canto e Música Sacra. E de fato, quer pela natureza desta arte de si flutuante e variável, quer pela sucessiva 
alteração do gosto e dos hábitos no correr dos tempos, quer pelo funesto influxo que sobre a arte sacra exerce a arte profana e teatral, quer pelo prazer que a música diretamente produz e que nem sempre é fácil conter nos justos limites, quer, finalmente, pelos muitos preconceitos, que em tal assunto facilmente se insinuam e depois tenazmente se mantêm, ainda entre pessoas autorizadas e piedosas, há uma tendência contínua para desviar da reta norma [...]. Todavia, como a música moderna foi inventada principalmente para uso profano, deverá vigiarse com maior cuidado porque as composições musicais de estilo moderno, que se admitem na Igreja, não tenham coisa alguma de profana, não tenham reminiscências de motivos teatrais [...]. Entre os vários gêneros de música moderna, o que parece menos próprio para acompanhar as funções do culto é o que tem ressaibos de estilo teatral (SOBRE MÚSICA SACRA, 1903, passim).

Apesar do consenso em relação à suposta decadência, os integrantes do Cecilianismo divergiam quanto ao modo de saná-la. Dentre as várias vertentes, uma defendia a restauração integral do repertório do passado no lugar da música do século XIX, outra via na emulação ou cópia estilística do repertório renascentista uma solução; numa terceira se encontravam os que optavam pela manutenção da linguagem romântica com a simplificação da escrita orquestral (GODINHO, 2008, p. 61). Pio X não oficializou nenhuma delas com exclusividade, ao contrário, todas elas parecem ter influenciado na redação do documento. 0 pontífice incentivou a restauração ao uso litúrgico da polifonia clássica (música renascentista), ao lado da chamada polifonia moderna, para a qual o cantochão e a polifonia de Palestrina serviriam como inspiração. O resultado foi o desenvolvimento do repertório restaurista, cujos compositores ficaram conhecidos por esta alcunha ou como geração do motu proprio (MARCO, 1993).

Apesar de existir um processo de legitimação do repertório pela tradição, a Restauração Musical Católica não se baseava exclusivamente nela, mas estava fundada em um amplo escopo de normas e em mecanismos de coerção às obras que estivessem em desacordo com tais normas. O motu proprio revela este controle normativo ${ }^{4}$, uma vez que deveria ser visto um código jurídico de música sacra. Para fazer cumprir suas determinações, Pio $X$ prescreveu a criação de organismos censores de atuação local. Assim, o controle das práticas musicais passaria a atingir não apenas a produção do repertório, ou seja, aspectos composicionais, mas também aspectos interpretativos nos templos. Tal controle se estendia, por exemplo, aos instrumentos permitidos ou proibidos de tomarem parte nas cerimônias litúrgicas: o órgão de tubos foi declarado instrumento oficial da Igreja Romana, ao passo que foram admitidos instrumentos de cordas e alguns de sopros, desde que guardassem as características de acompanhamento do órgão, ou seja, de simples sustentação do canto. Foram proibidos, por outro lado, o piano, os "instrumentos estrepitosos" de percussão, dentre outros, considerados profanos por remeterem à música dos teatros. A atuação de bandas de música foi limitada às procissões, acompanhando cânticos. No Brasil existiu, entretanto, uma massiva presença de banda no interior dos templos na primeira metade do século $X X$ e até mesmo o uso de tímpanos em algumas igrejas, conforme demonstraram nossas pesquisas (DUARTE, 2016), revelando um caráter de negociação em relação aos paradigmas de Roma.

O caráter de negociação que se dá em relação às normas conduz a uma abordagem da Igreja Católica não como uma instituição monolítica, mas enquanto sistema social no qual operam partes ou níveis que procuram garantir seus interesses, em acordo ou não com as metas globais do sistema. Somam-se a estas forças internas os estímulos provenientes do entorno, com o qual o sistema se comunica constantemente. Trata-se, portanto, de um sistema aberto, mas operacionalmente fechado a fim de resguardar sua identidade. Niklas Luhmann (1995) utilizou a expressão fechamento normativo para descrever tal preservação da identidade de um sistema social, ao passo que, por meio da abertura cognitiva este sistema alteraria suas metas ou características internas a partir dos estímulos do entorno. Walter Buckley ([1971]) destacou, por sua vez, que a existência de ações oriundas de partes ou níveis do sistema em desacordo com as metas globais deste - o comportamento aberrante - é comum e necessário para as mudanças do próprio sistema em face de novos estímulos do entorno. Neste sentido, as negociações em relação às normas papais se revelam uma prática corriqueira do 
sistema religioso, inclusive no que diz respeito ao repertório musical.

As metas do movimento de Restauração Musical somente saíram do plano das ações isoladas ou expectativas de especialistas para o plano hegemônico por integrarem de maneira coerente um discurso identitário que se estruturava durante o século XIX. Estas metas que propunham o isolamento da música religiosa de tudo o que fosse profano ou teatral encontraram eco na Romanização, que foi a resposta do sistema religioso às mudanças pelas quais passava a Igreja Católica no século XIX, tais como a perda da condição de religião oficial em diversas nações, o ensino laico, leis de divórcio e casamento civil, dentre outros. A Romanização reforçou o Ultramontanismo, uma autocompreensão que tinha em sua base a obediência irrestrita ao papa, a educação e moralização do clero, além de um forte senso de unidade e institucionalização. Esta autocompreensão monolítica era legitimada, pelo que Joël Candau (2011) denominou grandes memórias organizadoras. Este tipo de memória funda identidades fortes, como é o caso da identidade nacional e, no caso do sistema religioso, o catolicismo romanizado. Neste último caso, as memórias foram retomadas do catolicismo medieval e do Concílio de Trento - representando a reação à "ameaça" do Protestantismo no século XVI.

A Romanização propunha para todas as igrejas do universo católico um único modelo de prática religiosa, centrado em Roma. Com isto, manifestações do catolicismo popular passaram a ser sistematicamente silenciadas, bem como passou a haver um controle pelo clero das agremiações religiosas até então geridas por leigos, as irmandades e ordens terceiras (WERNET, 1987). Caracteriza ainda a Romanização uma extensa condenação aos "vícios da modernidade" por meio do documento papal Syllabus errorum, de 1864, bem como um juramento antimodernista, que, sendo exigido dos clérigos, acabou por limitar e desacreditar quaisquer novas correntes teológicas (DUFFY, 1998, p. 251). Percebe-se, portanto, a existência de relações de poder no processo de implantação desta autocompreensão do catolicismo, que foi recebida localmente de distintas maneiras pelos clérigos e fiéis, da aceitação à declarada resistência, passando por distintos processos de negociação.

\section{A BUSCA PELA IDENTIDADE NACIONAL E A FIGURA DO PADRE JOSÉ MAURÍCIO}

Se a identidade forte da Romanização se legitimava a partir dos passados tridentino e medieval, a almejada identidade nacional brasileira também deveria encontrar, no século XIX, as bases sobre as quais haveria de se assentar. Após a independência, a antiga colônia portuguesa haveria de buscar sua identidade e escrever sua própria história. Assim, foi criado o Instituto Histórico e Geográfico Brasileiro IHGB, em 1838, inspirado no Institut Historique parisiense. O interesse na produção de uma história oficial capaz de, nos termos de Jacques Le Goff (1990, p. 447), alimentar a memória coletiva, foi estimulado por Dom Pedro II, que frequentava as sessões do Instituto. A aproximação entre Brasil e França é, entretanto, muito mais ampla. Ciclos econômicos exitosos na segunda metade do século $X I X$ e início do $X X$ - dentre os quais, os do café, algodão e látex levaram à reurbanização e um afrancesamento das características arquitetônicas de diversas cidades na chamada Belle Époque brasileira. Este movimento veio acompanhado de uma crença de que o progresso material seria capaz de "equacionar todos os problemas da humanidade" (FOLLIS, 2004, p. 15). Associada a isto, havia uma tentativa de esquecimento do passado colonial. Neste ambiente, desenvolviase um habitus ${ }^{5}$ pretensamente europeu entre a parte mais abastada da sociedade, que legitimava seus comportamentos a partir de referenciais europeus, revelando a busca por um processo civilizador (ELIAS, 1994, p. 170). Neste ambiente, a Romanização católica - que era eurocentrista em suas bases - encontrou as condições ideais para se desenvolver.

As teorias raciais compõem ainda o panorama do surgimento da identidade nacional. Inicialmente, "o índio foi tornado símbolo de independência espiritual, política, social e literária" por meio de um indianismo literário que desenvolvia um mito de fundação capaz de unir "a doutrina do 'bom selvagem' de Rousseau com as tendências 
lusófobas" (COUTINHO, 2004, p. 24). Ainda nos tempos de colônia, havia uma expectativa de que a branquidão, "ligada ao capitalismo e ao progresso", poderia "eclipsar a negritude" no Brasil:

O filho mais velho e herdeiro de D. João VI de Portugal era agora [após a Independência] Pedro I, imperador do Brasil. Tanto ele quanto seu filho, que viria a se tornar o imperador D. Pedro II, viam como problemática a composição racial e étnica (ambos os termos eram usados na época) de sua nova nação. Em sua opinião, como na de muitos outros integrantes da florescente elite brasileira, escravos, povos indígenas, negros libertos e mestiços, muitas vezes chamados de pardos, nunca viriam a construir um país moderno (LESSER, 2015, p. 34-55).

Merece destaque o duplo papel que as artes passaram a assumir no Império e inícios da República: reforçar características comuns aos brasileiros, mas também de morigeração cultural, ou seja, refinar os costumes, por meio, inclusive, da fundação de sociedades de concertos (ANZÉ; CARLINI, 2009). A construção de teatros inspirados em teatros franceses em diversas capitais brasileiras reforça ainda o intuito de europeização da Belle Époque nos trópicos.

Já no século XX, o índio perdeu a exclusividade na mitificação fundacional para integrar, juntamente com o negro e o português, um novo mito de fundação ${ }^{6}$, baseado na fusão destas raças. Este mito desconsiderava a existência da imigração de vários outros povos para o Brasil e tentava suavizar ou mesmo esquecer toda a violência envolvida nos processos de encontro e fusão dessas raças. A associação entre música e raça em José Maurício Nunes Garcia foi abordada por Marcelo Hazan (2008). Esta relação se observa desde o primeiro artigo sobre padre José Maurício, de Manuel de Araújo Porto-Alegre - Ideias sobre a música, de 1836 - até a era Vargas, quando a mestiçagem passou de "fator de atraso" a mito de fundação. Porto-Alegre exaltava a aproximação de padre José Maurício dos compositores germânicos do Classicismo como forma de legitimar a identidade musical do clérigo brasileiro. Décadas mais tarde:

Durante o governo Vargas é codificado um novo sistema simbólico para a nação [...]. Feijoada, capoeira, samba e candomblé são significados como traços culturais mestiços. Enaltecendo a tolerância da sociedade brasileira, o Dia da Raça, é acrescido ao calendário cívico. Nesse mesmo período o Brasil ganha a sua padroeira,
Nossa Senhora da Conceição Aparecida, uma santa mestiça. A música sacra de José Maurício pode não ser um elemento óbvio dentro desse imaginário, porém a ele efetivamente pertence. A demonstração dessa pertença, contudo, dado o espaço surpreendentemente pequeno que coube à música no pensamento freyreano, requer um aceno à obra musicológica de Mário de Andrade e seus sucessores nacionalistas. A história da música brasileira tinha o seu grande mestre, um mestre mulato, como era o Brasil. Aos musicólogos cabia casar a arte de José Maurício com a cor de sua pele, isto é, demonstrar que sua música era genuinamente mulata e brasileira, não branca e germânica (HAZAN, 2008, p. 35).

No interstício destas duas perspectivas desponta a figura do maior defensor do mito mauriciano, Alfredo d'Escragnolle Taunay (1843-1899), o Visconde de Taunay, um dos políticos brasileiros favoráveis ao branqueamento da nação, inclusive por meio do estímulo à imigração. Seu entusiasmo com a cultura germânica explica seu apreço pela obra de José Maurício, a qual se legitimaria, sobretudo, pela semelhança com a música de Joseph Haydn. Visconde de Taunay e o compositor cearense Alberto Nepomuceno (1864-1920) viriam a compartilhar, além do interesse pela obra de José Maurício, a participação em um projeto de Restauração da Música Católica no Brasil antes mesmo da promulgação do motu proprio de Pio X, de 1903.

\section{JOSÉ MAURÍCIO E AS RESTAURAÇÕES DA MÚSICA CATÓLICA NO BRASIL}

A empreitada da Restauração Musical católica não avançou no mesmo ritmo no vasto território brasileiro. Enquanto fontes musicais demonstram que até fins da terceira década do século $X X$ ainda havia intensa prática da música dita teatral em algumas regiões, em outras se percebem esforços de restauração antes mesmo de 1903. Tais esforços ocorreram nas capitais dos estados do Pará, Ceará e, sobretudo, no Rio de Janeiro. As publicações dos frades franciscanos alemães na então capital federal contribuíram para que se traçasse um novo caminho para o repertório litúrgico. Em 1899, frei Pedro Sinzig lançava Benedicte, uma coleção de cantos religiosos populares em vernáculo para as missas baixas ${ }^{7}$, a exemplo do que os padres lazaristas já haviam realizado em Mariana, em 1967. Tais coletâneas foram muito recorrentes no Brasil na primeira metade do século XX. 
Antes da publicação de Sinzig, já circulava no Rio de Janeiro um projeto do crítico José Rodrigues Barbosa (1857-1939) para que a música litúrgica fosse restaurada, uma série de artigos publicados entre 1895 e 1898 no Jornal do Commercio (VERMES, 2000). A renovação da música palestriniana e do cantochão, bem como a criação de uma "associação" destinada a "dar à música de igreja seu verdadeiro caráter e afastar dos templos os sinfonistas e compositores profanos" e animar os "músicos modernos que queiram escrever obras puramente religiosas e consentâneas com as regras da liturgia católica" eram os principais intuitos da proposta de Rodrigues Barbosa (GOLDBERG, 2004, p. 141-142). Este projeto logo encontraria a adesão do compositor Alberto Nepomuceno, que também se envolvera no projeto de recuperação e publicação das obras do padre José Maurício desenvolvido pelo Visconde de Taunay. O próprio Taunay teria apoiado o projeto de restauração de Barbosa, de modo que as causas da restauração da música sacra e do resgate de José Maurício logo se confundiram. Se a campanha de Barbosa não logrou êxito inicial com o arcebispo do Rio de janeiro, D. João Esberard, seu sucessor, D. Joaquim Arcoverde Cavalcanti parece ter dado maior atenção à causa, chegando solicitar do clero local, em 1898, a nomeação de uma comissão para analisar o assunto. Esta comissão foi constituída por oito membros, dentre os quais, Alberto Nepomuceno e Taunay.

O resultado dos trabalhos foi a elaboração do Projeto do Regulamento de Música Sacra da Arquidiocese de São Sebastião do Rio de Janeiro, de 1898, muito semelhante, na maioria de seus artigos, ao que viria a ser publicado posteriormente no motu proprio de Pio X, propondo, inclusive, a criação de uma "Comissão Gregoriana", que funcionaria como censora das obras adequadas ou não à liturgia. Os autores do Projeto de Regulamento... tinham claras as discussões em torno da Restauração Musical correntes na Europa, inclusive de um decreto da Sagrada Congregação dos Ritos sobre a música sacra de 1894, que já vislumbrava os ideais da Restauração. Se em Fortaleza regulamento semelhante fora aprovado anteriormente ao motu proprio, na Arquidiocese de São Sebastião do Rio de Janeiro os esforços restauristas não lograram o mesmo êxito. Somente na década de 1920 o cenário se modificaria, a partir da redação da Circular do Excelentíssimo Monsenhor Vigário Geral do Arcebispado do Rio de Janeiro sobre a Música Sacra, de 1921, que reforçava a necessidade de aplicação dos paradigmas contidos no motu proprio de Pio $X$ (GOLDBERG, 2004, p. 150). Um dos grandes incentivos oficiais à Restauração Musical foi o Concílio Plenário Brasileiro, de 1939, que contou com sessões de trabalho destinadas a discutirem exclusivamente a questão da música. Não parece simples acaso que na década de 1940 os franciscanos do Rio de Janeiro tenham lançado o periódico Música sacra, que chegou a ser indexado internacionalmente entre as publicações do gênero. Décadas após o projeto frustrado de Rodrigues Barbosa, Nepomuceno, Taunay e outros, a tão aguardada Restauração Musical católica finalmente poderia ser considerada oficial no Brasil, tendo a revista dos franciscanos como seu arauto. Nela se encontram as principais discussões acerca da obra musical de José Maurício Nunes Garcia e de outros compositores coloniais neste período. Por meio das críticas da Comissão Arquidiocesana de Música Sacra é possível conhecer o tratamento dispensado pela Igreja a tais compositores. O quadro social na década de 1940 era bastante diverso daquele do início da República. Se a Belle Époque brasileira foi marcada pela exclusão de negros e mestiços, Durante a Era Vargas:

A modinha, valorada como música mestiça e matéria-prima para a composição erudita, encarnou uma individualidade cultural nacional consistente com o relaxamento dos limites raciais da nação, com vista à cooptação da população afrodescendente. A transformação da mestiçagem de causa dos males do país em fonte de orgulho nacional, passando por solução branqueadora, demarcou o percurso pelo qual se enveredou a recepção do compositor mulato José Maurício Nunes Garcia. Suas encarnações sociais evidenciam como a busca, na Europa, de modelos para a criação musical deu lugar à procura, no Brasil, de maneiras de se expressar a brasilidade através da música. José Maurício não apenas foi arregimentado em prol da grande arte austro-germânica, da qual era considerado herdeiro, mas também em favor da tradição nacional-modernista, da qual era considerado pai. Esses processos ideológicos de conformidade cosmopolita e individualidade 
nacional traduziram-se na construção de duas genealogias mauricianas, a primeira partindo de Haydn e a segunda culminando em Villa-Lobos. O "clássico brasileiro" transformou-se, assim, no "brasileiro clássico" (HAZAN, 2008, p. 38).

Estes novos paradigmas viriam a se refletir na revista Música sacra de Petrópolis. Nesta fase consolidada da Restauração Musical, da década de 1940:

A campanha a favor de José Maurício não incompatibiliza com o esforço de esquecimento do passado colonial, já que em sua obra se encontrariam raízes nacionais autênticas (momento de fundação) e a corrupção foi representadapelocolonizador. Assim, se defender o compositor mulato poderia representar um contra-senso em relação à Restauração Musical, no plano mais amplo de esquecimento do passado colonial e lusitano, sua imagem poderia ser ressignificada e transformada na de um herói. Ademais, o mito mauriciano foi estimulado por Taunay e Nepomuceno e acabou por se confundir com a defesa da restauração musical litúrgica anterior ao motu proprio, proposta por este último no Rio de Janeiro (DUARTE, 2016, p. 316).

O referido contrassenso estaria na assimilação literal de elementos da nacionalidade na música litúrgica, o que era proibido pelo motu proprio. No documento de Pio $X$, o canto religioso popular - com texto em vernáculo - era, dentre as categorias de música litúrgica, aquele que haveria de expressar a índole de cada povo particular, mas mesmo assim deveria guardar esta universalidade de caráter eurocentrista ${ }^{8}$. A música sacra de José Maurício nada assimilava, na prática, da música popular urbana de seu tempo, mas isto não impediu que o crítico Luís Heitor Corrêa de Azevedo procurasse adequar sua memória às necessidades do propalado mulatismo, sobre o qual se assentavam o mito das três raças e o nacionalismo corrente:

Num Tantum ergo de 1798 o $1^{\circ}$ violino (na partitura designava como rabeca) tece este canto tão profundamente brasileiro, que trai no compositor sacro o antigo mocinho cantador de xácaras e modinhas ao violão [exemplo musical]. Não há aí um compromisso entre a arte brejeira do mulato fluminense e a serena elevação da música sacra? Não guardam essas harmonias a pureza de uma, apesar de rescenderem o aroma fortemente popular da outra? [...] Numa delas ["Novena do Apóstolo São Pedro"] encontramos a seguinte passagem que Francisco Manuel certamente tinha na memória ao escrever as páginas ardentes do Hino Nacional (AZEVEDO, 1946, p. 88).
José Maurício se torna, nestas palavras, um protótipo da nacionalidade atribuída a Heitor Villa-Lobos, uma nacionalidade que tem no violão e na música popular urbana - seja a modinha colonial ou o choro do início do século $X X$ - seus ícones. Neste mesmo sentido se encaminharia mais tarde a interpretação de Cleofe Person de Mattos, que foi provavelmente, na musicologia brasileira, quem mais se deteve no estudo de fontes musicais de José Maurício. No momento histórico em que o Luis Heitor redigia seu artigo havia, entretanto, um claro descompasso entre a música litúrgica e a música de concerto, no que diz respeito à assimilação de elementos da cultura nacional provenientes da música popular a guardavam: nos templos soavam músicas de características essencialmente europeias, enquanto nos teatros, a exploração de características indígenas já se fazia sentir desde fins do século XIX (MOREIRA, 2016). Composições litúrgicas com utilização literal de elementos musicais de culturas não europeias passaram a ser compostas somente na década de 1950, no período conhecido como Aggiornamento da Igreja Católica. Apesar disto, o artigo de Luís Heitor foi reproduzido no periódico Música Sacra. Ainda que o discurso da Romanização apontasse para o completo fechamento normativo (LUHMANN, 1995) no sentido de transcendência em relação aos "vícios da modernidade", fato é que este fechamento não impediu a comunicação do sistema religioso com o entorno. No referido artigo é possível observar o caráter lusófono que marca a busca da identidade nacional pela via da alteridade:

Em 1808, quando a Corte Portuguesa desembarca no Rio de Janeiro, José Maurício está no apogeu de sua força criadora. [...] Ele tentava resistir, pois, à onda de mau gosto que a Corte trouxera consigo [música religiosa italiana do século XVIII]. Mas isso era difícil. Toda aquela gente de sangue limpo que vinha da culta Europa, que pelo nascimento e pelas posições estava acima do humilde compositor colonial, todos os músicos da Metrópole - inclusive esse Marcos Portugal [...] A saúde está alquebrada, aos cinquenta anos [...] Não tem mais forças para opor à invasão do mau gosto. [...] No seu espírito cansado e envelhecido precocemente acabara predominando o gosto depravado dos grandes senhores de além-mar para os quais as solenidades de Igreja eram um pretexto de diversões mundanas, transformando o templo numa feira de ostentação, de vaidades e de galanteria onde iam ouvir música fácil e sensual, sermões literários e forjar histórias de amor... (AZEVEDO, 1946, p. 85-94). 
Percebe-se, portanto, uma recriação da memória: a música de José Maurício que não escapava à teatralidade de seu tempo, mas suas "falhas" foram atribuídas ao "gosto depravado" Iusitano, sendo este a causa para sua "decadência". Assim, se observa que, longe da pretensa objetividade da história, os resgates do passado pela via da memória são fruto das necessidades dos indivíduos no presente, donde derivam inúmeros processos de adaptação dos acontecimentos pretéritos a esta necessidade? Mais do que a identidade de um grupo específico, a memória de José Maurício se liga à identidade nacional, uma identidade forte que depende de heróis e grandes memórias organizadoras, passíveis de compartilhamento, ainda que de maneiras distintas ${ }^{10}$, pelos indivíduos integrados por meio dessa identidade.

Para garantir a coerência da obra de José Maurício no cenário da Restauração Musical, seria necessário adequar esta memória musical às necessidades do presente. Foi o que fizeram Sinzig e Nepomuceno, reforçando o argumento de Luís Heitor de que o profano em suas obras se encontrava no acompanhamento e não na melodia: três das composições aprovadas pela CAMS-RJ11 foram arranjadas por Sinzig, Ave Maris Stella, Tantum ergo e Verbum caro factum est; já a Missa em Si bemol foi editada por Nepomuceno e Lux aeterna, por José Capocchi. As outras obras de José Maurício aprovadas pela Comissão foram: Hino das Matinas da Festa da Santíssima Virgem, Lux aeterna, Missa em Si bemol e Responsório das Matinas de Natal (DUARTE, 2016, p. 316-317).

Longe da preocupação estilística e com as fontes primárias que caracteriza o trabalho científico do musicólogo, as intervenções propostas pelos defensores da Restauração Musical tinham um caráter ideológico e não raro produziram um acompanhamento instrumental de tal modo diverso do acompanhamento escrito por José Maurício que as obras somente seriam reconhecidas graças à melodia. Lê-se sobre uma edição:

493 - P. José Maurício Nunes: LUX AETERNA. [...] arranjo para voz média por J. Capocchi [...] Não é a primeira vez que M:SICA SACRA e o LIVRO DE OURO falam do Padre José Maurício que, em seu tempo, foi o expoente máximo da música no Brasil e cujas obras, em grande parte, ainda hoje, merecem acatamento e admiração. Tem composições sacras de inteiro acordo com as leis litúrgicas [...] Na instrumentação, o Padre José Maurício se mostra digno discípulo de José Haydn, escrevendo com fluência e bom gosto que impõem e que, com meios simples, conseguem lindos efeitos. [...] A conservação das expressões originais de andamento podem levar a inconvenientes [...] As apojaturas, tão em uso aos tempos do P. José Maurício, foram conservadas pelo editor, por respeito à tradição, em "aeternam" e "perpetua", e, na segunda voz, num "Domine" e "eis", mas o caráter sacro e a linha melódica, principalmente em Missa pelos Defuntos, com a supressão só poderão ganhar. Arpejos e a repetição de notas para efeitos rítmicos [...] ficam melhor para piano que, para acompanhamento na igreja, naturalmente está excluído. [...] Frei Pedro Sinzig O. F. M.

A indicação no título que o órgão pode ser substituído por piano, sem dúvida, se refere ao canto da composição em casa, porque na igreja, o piano não é admitido. [...] Uma vez ou outra J. Cappochi parece ter querido atender ao piano, quando, no mais, seguiu os princípios impostos pelo caráter do órgão. [...] As poucas "appoggiaturas" que o editor julgou dever respeitar, eram, sem dúvida, do gosto do século passado, mas, de há muito, deixaram de sê-lo; eu não teria dúvida em riscá-las para o coro que me cumprisse reger ou se eu mesmo tivesse que cantar. $O$ andamento do canto, sem dúvida, deverá tomar em consideração que se trata de música sacra [...] Frei Valdomiro Chatas, O. F. M. (CAMS-RJ, 1944a, p. 159).

Assim, observa-se que, em nome de uma expectativa compartilhada de sacralidade, a obra poderia passar por intervenções profundas. Outro aspecto relevante na crítica de Sinzig é o fato de José Maurício figurar como mito fundador da nacionalidade até mesmo no âmbito da censura musical católica, ainda que a partir de argumentos mais próximos daqueles apresentados por Taunay - de aproximação entre o indígena e o "universal" - do que de exaltação do mulatismo, como já revelavam as críticas de Luís Heitor. Há de se notar ainda que grande parte das obras de José Maurício merecesse acatamento e admiração na década de 1940, revelando sua continuidade na prática musical litúrgica. Não é demais lembrar que monsenhor Guilherme Schubert noticiou o uso litúrgico das obras de José Maurício em fins do século XIX, certamente mais próxima da concepção estilística do compositor:

Assim não estranhamos o desabafo do Visconde de Taunay, pouco antes de sua morte (+ 25/11/1899): “Fui ouvir a 'Missa Mimosa' do Padre José Maurício na Igreja da Cruz dos Militares... Segundo as "boas tradições" que todo o empenho e esforço da comissão de música sacra não poderão abalar, começou a cerimônia religiosa 
pela ouverture, tão ouvida, corriqueira e estafada da Gazza ladra de Rossini. Adequado preparo para uma função religiosa, aquela saltitante protofonia da "Pega ladra"! Enfim, seja tudo pelo amor de Deus! (SCHUBERT, 1980, p. 20).

Segundo esta citação existiria uma tentativa de censura à obra de caráter mais teatral de José Maurício por parte dos partidários da Restauração musical, mas tal seria seu vínculo com a tradição musical vigente no Rio de Janeiro que os esforços restauristas não seriam capazes de conseguir seu banimento dos templos. A estratégia de produzir arranjos da obra mauriciana parece, portanto, uma negociação em relação ao mito fundador da brasilidade musical, a fim de sacralizar de algum modo aquilo que seria por eles considerado profano. Sua conversão à Restauração musical haveria de se operar principalmente por meio da reforma do acompanhamento instrumental, considerado profano, mesmo por Luís Heitor:

[A música sacra de José Maurício Nunes Garcia] É, porém, expressiva, singela, repassada, às vezes, de unção verdadeiramente celestial. Abusa um pouco do cromatismo e de certos retardos que lhe emprestam o cunho de modinha sentimental, em algumas passagens. A maneira do compositor tratar as vozes é sóbria, de caráter austero e irrepreensível; quase sempre vertical. Aos instrumentos da orquestra é que ele confia àquelas veleidades mundanas da sua inspiração; há melodias surpreendentes, desenhos deliciosos, contrapondo-se às linhas simples e largas das vozes (AZEVEDO, 1946, p. 87-88).

É na crítica à Missa em Si bemol, contudo, que fica evidente que o valor da obra artística estaria em sua aproximação dos modelos europeus, reforçando ainda o processo civilizatório vigente na Belle Époque brasileira. A universalidade eurocêntrica do motu proprio marca o tom do discurso de Pedro Sinzig:

511 - Padre José Maurício Nunes Garcia: MISSA EM SI BEMOL para solos e coros com acompanhamento de orquestra reduzida para órgão ou harmônio por Alberto Nepomuceno [...] Precedida de um esboço biográfico do autor pelo Visconde de Taunay [...] escreve [...] Taunay: "Empregando todas as suas economias em ajuntar a mais vasta coleção existente de composições musicais de todos os autores alemães, italianos e franceses então existentes, sempre e sempre aumentada e que em 1816 produziu a maior surpresa a Sigismundo Neukomm, o discípulo querido de Haydn, filiou-se instintivamente à grandiosa e severa escola de Haendel, Haydn, os Bach, Mozart, Beethoven, este já a emergir nos largos horizontes da arte, como astro de inexcedível brilho. [...] pode dividir-se a obra do grande compositor sacro em dois períodos: o primeiro, de máxima valia e pureza, originado na genuína fonte germânica e que decorre de 1790 a 1816, nada menos que 26 anos; o segundo, já de adulteração e decadência em que... aparecem os sinais de deplorável depressão, devido à influência do mau gosto e da escola italiana [...]".

Sem dados positivos, julgamos, contudo, que a Missa supra é do $1^{0}$ período, tal a sua feição, digna e elevada. Há trechos que obrigam a reparos; procuramos interpretá-los com o respeito e admiração que nos merece o autor. [...] A "redução para órgão ou harmônio", no entanto, não atendeu sempre ao caráter desses instrumentos eclesiásticos. [...] Alberto Nepomuceno transcreve para o órgão as frequentes repetições de notas, próprias dos instrumentos orquestrais, em vez de ligá-las como se costuma fazer no órgão. [...] Abstraindo a falta de unidade que pode e deve ser estabelecida, o CREDO (para não falar de outras partes) pode ganhar notável ou essencialmente em religiosidade com alguns retoques, respeitosos, mas firmes [...] Eu não teria entrado em tantos pormenores, se a Missa em si bemol e, principalmente, seu autor não me merecessem tudo. [...] Frei Pedro Sinzig, O. F. M. (CAMS-RJ, 1944b, p. 219).

Com todos os "respeitosos retoques" propostos por Sinzig, não parece exagero pensar que o resultado musical seria comparável à reforma de uma igreja colonial que resultou em uma fachada neogótica. É importante relembrar que Pedro Sinzig era um missionário de origem alemã que se propunha a difundir referenciais de sacralidade que foram defendidos com particular entusiasmo pela Associação de Santa Cecília da Alemanha, a primeira do gênero no universo católico. A diferença no tratamento dispensado pelo religioso a outros compositores da capela da Sé Imperial denota o poder do mito fundador mauriciano: sua condenação à obra de Sigsmund Neukomm reflete a crítica ao "gosto depravado" que teria chegado ao Brasil com a realeza:

$2^{0}$ - RECUEIL DE CINQUANTE MOTETS [...] [Coletânea de cinqüenta motetos para todas as solenidades do ano litúrgico, pras bênçãos do Santíssimo Sacramento e festas da Santíssima Virgem. Música composta para uma ou duas vozes, em solos e coro com acompanhamento de órgão, pelo senhor Sigismund Neukomm]. [...] Insinua-se ao ouvido e ao coração a música de Neukomm como poucas. Para fins de estudo técnico eu quereria chamá-la de exemplar. [...] Para festas religiosas fora da igreja, para cantatas e oratórios de Natal, da Quaresma, da Páscoa etc., não poucos números 
poderão prestar bons serviços; no entanto, para o canto dentro da igreja falta o espírito religioso que distingue a música sacra da que não se destina à casa de Deus. Qualquer um desses textos musicados por um Palestrina, um Griesbacher, fala profundamente ao coração e à consciência, quando na veste musical dada por Neukomm se apresenta faceira e sentimental; é um passatempo agradável, mas não eleva a alma nem a purifica. [...] Que pena, um talento como o de Sigismundo Neukomm, não nos ter dado música realmente sacra!... (CAMS-RJ, 1946b, p. 20).

Assim, observa-se que as obras de Neukomm sequer seriam merecedoras de "respeitosos retoques", a fim de garantir sua execução nos templos, ainda que fossem semelhantes em muitos aspectos. Diante deste quadro, é impossível negar que a música de José Maurício não somente desfrutava de uma condição particular se comparada à de seus pares. Isto fica evidente também em uma fonte da Missa em Si bemol no Acervo João Mohana, recolhido ao Arquivo Público do Maranhão, que traz em uma parte de violino uma imagem de José Maurício em um recorte com os seguintes dizeres: "[...] Foi, segundo o Visconde de Taunay, o "gênio da música no Brasil'. Morreu a 18 de abril de 1830" (GARCIA, [19--]b, f.1). A considerável distância entre o Maranhão e o Rio de Janeiro revela a difusão do mito da brasilidade propalado por Taunay. Também na partitura de canto e harmônio é possível notar não apenas uma ilustração de José Maurício, mas também um pequeno esboço biográfico baseado em Taunay, sugerindo que a fonte maranhense se trate de um arranjo produzido localmente a partir da edição de Alberto Nepomuceno.

\section{OS IMPACTOS DA BUSCA POR UMA NOVA NACIONALIDADE NA MÚSICA LITÚRGICA}

Como já foi dito, a busca por referenciais indígenas para a construção de um repertório nacional de concerto - inclusive com a exploração de temáticas e de temas musicais indígenas - foi uma prática corrente no Brasil, e de maneira mais ampla, na América Latina, desde finais do século XIX. Os compositores Carlos Gomes, Heitor Villa-Lobos, Roberto Ojeda Campana, Carlos Chávez, Alberto Villalpando, representam - cada qual à sua maneira - esta busca pela música indígena (MOREIRA, 2016). Na música católica praticada no Brasil, o referencial da grande memória organizadora nacional (CANDAU, 2011), José Maurício Nunes Garcia se estabeleceu a partir de argumentos que buscaram legitimar sua obra a partir de referenciais europeus, tal como procedera anteriormente o Visconde de Taunay.

Entre finais da década de 1940 até o Concílio Vaticano II (1962-1965), a Igreja Católica experimentou uma abertura cognitiva (LUHMANN, 1995) às culturas não europeias, que influenciou profundamente as metas musicais pós-conciliares. A Encíclica "Mediator Dei" de Pio XII, de 1947, é uma referência para este movimento. Neste período conhecido como Aggiornamento - no sentido de atualização foram compostas obras musicais que revelavam musicalmente a índole de cada povo particular. Um exemplo é a Missa Luba, composta em 1958 pelo franciscano Guido Haazen no Congo Belga.

\begin{abstract}
A Igreja Católica, provavelmente sob o impacto desse processo de descolonização dos países africanos e asiáticos, acompanha o mesmo movimento. Já nos anos 50 começou a sublinhar a importância da 'adaptação' do cristianismo aos valores das outras culturas. Com o Concílio Vaticano II, porém, tornou-se evidente o fato de que parte do clero provinha de culturas não européias e a noção de adaptação cedeu lugar à afirmação da igualdade entre as culturas (MONTERO, 1992, p. 93).
\end{abstract}

Este movimento de reconhecimento de culturas não europeias viria a culminar com a equiparação entre o valor das culturas de países europeus e de outros continentes durante o Concílio Vaticano II, fato que implicou maior liberdade na determinação das metas musicais do sistema religioso também no Brasil. A partir de então, dois estudos da Conferência Nacional dos Bispos do Brasil (CNBB), A música litúrgica no Brasil (CNBB, 1976) e Pastoral da Música Litúrgica no Brasil (CNBB, 1998) passaram a se valer da noção de música indígena para caracterizar a expectativa de uma completa renovação do repertório litúrgico, processo chamado de inculturação litúrgica e musical. Quando ganhou força no Brasil, na década de 1970, o movimento de inculturação passou a apontar como rumos para a renovação do repertório não a noção de música indígena próxima da música de concerto, mas da Nova cançãolatino-americana ou canção de protesto. O novo repertório ritual católico passou a ter nos ritmos populares e da dita música folclórica suas bases (DUARTE, 2014). 0 
mito das três raças permeia os documentos da CNBB, quando estes se referem às fontes para a construção da nova música litúrgica. O resultado da implantação destas novas metas foi, de fato, a renovação do repertório ou nos dizeres de Walter Buckley ([1971]), uma morfogênese, que implicou o esquecimento de parte considerável do repertório pré-conciliar, sobretudo, daquele composto sobre textos em língua latina. 0 canto pastoral de características indígenas passou a assimilar ritmos populares (samba, xote, baião e outros) e teve uma considerável simplificação das texturas, do canto coral para o canto uníssono. A escolha dos instrumentos acompanhadores também reflete esta renovação: o violão e os instrumentos percussão passaram a assumir - lugar antes ocupado pelo órgão. Neste processo, a obra sacra de José Maurício foi confinada às salas de concerto, que passaram a funcionar também como lugares de memória (NORA, 1993) da música litúrgica: afastada do cotidiano e sem uma clara função nas igrejas, seu esquecimento é detido fora da liturgia, provavelmente muito mais em razão do serviço que o compositor prestou à nação - servindo à construção de um mito de brasilidade musical do que por aquele que prestou à Igreja.

No catolicismo dos dias atuais se percebe, entretanto, uma tendência à valorização da memória pré-conciliar, sobretudo após o motu proprio "Summorum Pontificum" - sobre a liturgia romana anterior à reforma de 1970 - de Bento XVI, promulgado em 2008. Este documento autoriza a celebração no rito préconciliar em língua latina (rito tridentino) sem a necessidade da expressa autorização da autoridade eclesiástica local, donde decorreu um fenômeno de multiplicação das missas celebradas pelo rito antigo. A partir deste fenômeno, ressurge a possibilidade da retomada da obra musical sacra do padre José Maurício Nunes Garcia na função para a qual foi criada.

\section{CONSIDERAÇÕES FINAIS}

Ao fim deste artigo, é possível afirmar, em resposta às problemáticas formuladas, que a manutenção da obra sacra do padre José Maurício Nunes Garcia nos ritos da Igreja Católica Romana no Brasil durante a primeira metade do século $X X$ não foi fruto de simples acaso, tampouco parece se justificar por razões puramente musicais ou religiosas. Ao contrário, um projeto de construção de um mito fundador da nacionalidade musical brasileira parece ter sido decisivo neste processo de manutenção. Longe de uma construção linear, esta memória se adaptou às necessidades e condições do presente, sobretudo no que diz respeito à questão da raça ou da etnia. Inicialmente a busca por equiparar a cultura musical indígena à europeia foi o principal argumento da crítica musical para a legitimação estética da obra de José Maurício. Depois, a valorização da mestiçagem, do mito das três raças, música popular e de elementos indígenas conferiram sustentação para o mito mauriciano da brasilidade musical. A questão da raça e da valorização do mulatismo não parece ter sido assimilada, entretanto, pela Igreja Católica nas décadas de 1940 e 1950, quando já era corrente na sociedade.

Apesar da publicação das críticas musicais de Luís Heitor Corrêa de Azevedo no periódico de música litúrgica de maior circulação no país no período - Música Sacra -, o principal argumento a conferir legitimidade à obra de José Maurício pela Comissão Arquidiocesana de Música Sacra do Rio de Janeiro foi no sentido de reforçar sua aproximação de modelos musicais europeus, sobretudo da obra de Joseph Haydn. Assim, a construção do mito mauriciano a partir da ótica do Visconde de Taunay se revelou muito mais adequada às metas musicais do catolicismo romano deste período do que os argumentos de Luís Heitor. Isto se justifica, sobretudo, pela noção de "universalidade" estabelecida no motu proprio de Pio X: longe da assimilação literal da índole musical de cada povo particular - como ocorreu a partir do Aggiornamento. As análises das obras de José Maurício pela Comissão de Música Sacra do Rio de Janeiro se pautavam, sobretudo, pelo afastamento que este repertório teria dos referenciais da ópera e sua aproximação da música que seria verdadeiramente adequada aos templos, apontando também o papel do compositor como mito fundador da brasilidade musical. O suposto afastamento da música teatral implicou profundas intervenções realizadas por compositores restauristas na música de José Maurício, por meio de edições impressas. 
Tais intervenções se deram principalmente no acompanhamento, adequando-o à maneira de executar ao órgão exigida pelo motu proprio, mas também na diminuição das ornamentações vocais, a fim de que soasse menos próxima dos referenciais operísticos. Assim, mais do que uma assimilação literal da obra, houve um processo de recriação e adaptação da memória musical às necessidades do presente. 0 mesmo tratamento não foi dispensado a outros compositores do Brasil colonial, como foi o caso de Neukomm. Ao contrário, nas críticas à obra sacra do compositor de origem estrangeira, esta sequer parecia ter alguma possibilidade de salvação a partir de arranjos ou da criação de acompanhamentos executáveis à maneira de órgão.

Percebe-se, portanto, que a obra religiosa de José Maurício fora tratada a partir de pressupostos que excediam o campo estrito da religião, trazendo para o universo religioso o anseio da criação de um herói nacional no campo da música. Longe do Rio de Janeiro, um recorte contendo uma citação a Taunay colado em uma partitura que hoje integra o Acervo João Mohana - recolhido ao Arquivo Público do Maranhão - reforça a propagação deste mito (GARCIA, [19--]a).

Após o Concílio Vaticano II, o advento de novas metas musicais religiosas no Brasil legou à obra de José Maurício Nunes Garcia aos teatros. Estas novas metas assimilaram, ainda que após muitas décadas, a busca pelo nacional por meio de uma assimilação do mito das três raças na construção de um canto pastoral de características indígena. Limitada a concertos e apresentações artísticas, a obra musical religiosa de José Maurício continua a servir à nação, muito mais do que à finalidade para as qual foi composta, que era servir a Deus ou à Igreja Católica. Com o advento de um resgate do rito tridentino, a partir do motu proprio "Summorum Pontificum" de Bento XVI, descortina-se a possibilidade de um retorno da obra musical religiosa de José Maurício dos palcos dos teatros para as funções litúrgicas no Brasil. Se a concretização desta possibilidade ocorrerá, caberá ao tempo revelar.

\section{NOTAS}

01. "Na primeira grande transformação da musicologia no Brasil, que ocorreu do início do século XX até meados da década de 1960, observou-se a transição de uma fase literário-musical para uma fase propriamente musicológica, na qual os trabalhos passaram a se enquadrar em uma espécie de gênero intermediário entre literatura e ciência, incluindo-se aí as assim denominadas "histórias da música brasileira" (ou "no Brasil") e suas congêneres, como as de Guilherme de Mello (1908), Renato Almeida (1926), Vincenzo Cernichiaro (1926), Mário de Andrade (1941), Renato Almeida (1942), Maria Luiza de Queirós Amâncio dos Santos (1942), Francisco Acquarone [c.1948] e Luís-Heitor Corrêa de Azevedo (1956), para citar apenas as mais conhecidas" (CASTAGNA, 2008, p. 34). Na fase científica, destacam-se os trabalhos de Cleofe Person de Mattos acerca da obra de José Maurício Nunes Garcia.

02. A pesquisa de campo para a realização da investigação de doutorado - da qual o presente artigo é um desdobramento - se estendeu a setenta cidades brasileiras, em todos os estados, perfazendo um total de mais de quinhentas instituições visitadas e efetiva pesquisa em cento e setenta e cinco delas.

03. Tal noção de dignidade e a representação de decadência se fazem sentir na introdução do motu proprio de Pio X: "Nada, pois, deve suceder no templo que perturbe ou, sequer, diminua a piedade e a devoção das fiéis, nada que dê justificado motivo de desgosto ou de escândalo, nada, sobretudo, que diretamente ofenda o decoro e a santidade das sacras funções e seja por isso indigno da Casa de Oração e da majestade de Deus. Não nos ocupamos de cada um dos abusos que nesta matéria podem ocorrer. A nossa atenção dirige-se hoje para um dos mais comuns, dos mais difíceis de desarraigar e que às vezes se deve deplorar em lugares onde tudo o mais é digno de máximo encômio para beleza e suntuosidade do templo, esplendor e perfeita ordem das cerimônias, frequência do clero, gravidade e piedade dos ministros do altar" (SOBRE MÚSICA SACRA, 1903).

04. "O controle normativo das práticas musicais na Igreja consiste na determinação de modelos 
por meio de normas objetivas - detalhistas, específicas, prescritivas ou proibitivas -, com vistas a uniformizar e conformar tais práticas às metas institucionais do sistema religioso em determinado momento histórico. Para tanto, a criação e as práticas musicais são controladas por órgãos específicos e se tornam passíveis de sanção, no caso de descumprimento e de recompensa (propaganda), em caso de adequação. Assim, o controle normativo se apresenta como um condicionamento a priori da liberdade de opções franqueada àqueles envolvidos na criação ou na prática musical pela tradição, compreendida como transmissão das distintas técnicas e estilos musicais em sua relação com os sistemas locais" (DUARTE, 2016, p. 96).

05. “Princípio gerador e unificador que retraduz as características intrínsecas e relacionais de uma posição em um estilo de vida unívoco, isto é, em um conjunto unívoco de escolhas de pessoas, de bens, de práticas" (BOURDIEU, 1992, p.3).

06. Diz-se mito porque "a tese de que os conceitos de identidade nacional adotados pela elite eram fundados na diluição das distinções étnicas deve, portanto, ser modificada para incluir a incorporação progressiva da multietnicidade no conceito de brasilidade" (LESSER, 2015, p. 23).

07. Também chamadas de missas rezadas. Há de se observar, entretanto, que a diferenciação entre os tipos de missa não se fazia em razão do canto. Na missa alta ou solemnis, havia a assistência de ministros, diáconos e um coro, ao passo que na missa baixa ou privata, o celebrante tomaria, ele mesmo, a parte do diácono e do subdiácono, donde resultaria um rito abreviado. Uma das possíveis razões para esta divisão estaria na celebração simultânea de vários padres própria dos mosteiros (FORTESCUE, 1914, p. 188190). A coletânea de cânticos espirituais mais difundida no Brasil neste período foi Harpa de Sião, organizada pelo padre verbita de origem alemã João Batista Lehmann.

08. "Por isso a música sacra deve possuir, em grau eminente, as qualidades próprias da liturgia, e nomeadamente a santidade e a delicadeza das formas, donde resulta espontaneamente outra característica, a universalidade. [...] universal no sentido de que, embora seja permitido a cada nação admitir nas composições religiosas aquelas formas particulares, que em certo modo constituem o caráter específico da sua música própria, estas devem ser de tal maneira subordinadas aos caracteres gerais da música sacra que ninguém doutra nação, ao ouvi-las, sinta uma impressão desagradável" (SOBRE MÚSICA SACRA, 1903, §2)

09. "A propósito da ligação entre memória e poder, 'a expressão coletiva da memória, ou melhor, da metamemória, não escapa à manipulação dos poderes mediante a seleção do que se recorda e do que consciente ou inconscientemente se silencia'. Essa seleção entre recordação e silêncio evidencia que a memória, embora na maioria das vezes esteja ligada a fenômenos de dominação, é objeto de contínua negociação porque está atrelada à seleção do que é essencial para construção da identidade do grupo" (SANTOS et al., 2011).

10. Mesmo as identidades coletivas fortes e as memórias a elas inerentes não são estanques, mas passíveis de distintas interpretações, tanto em períodos distintos, quanto em uma mesma época, por grupos sociais distintos, ou como preferimos abordar, por distintas partes de um sistema social. Exemplo disto se observa no trabalho de Lesser $(2015,23)$ acerca da identidade nacional enquanto fruto da interação entre locais e estrangeiros, não como identidade única "da qual os residentes e cidadãos participam ou não participam de forma absoluta. Pelo contrário, os imigrantes e seus descendentes se beneficiaram muito ao abraçar tanto a imagem de uma nacionalidade brasileira uniforme quanto suas novas etnicidades pósmigratórias. Com isso, eles puderam se utilizar de símbolos múltiplos, mutáveis e muitas vezes contraditórios". A partir do século XIX, "nunca houve uma identidade nacional única ou estática: a própria fluidez do conceito faz com que ele esteja aberto a intervenções vindas de um ou de outro lado. Embora existisse um discurso elitista relativamente coerente, que via a etnicidade como algo traiçoeiro e pretendia constranger ou coagir os novos residentes a aceitarem uma identidade nacional europeizada, branca e homogênea, esta postura não era única".

11. Códigos das aprovações no Livro de Ouro do periódico Música Sacra, respectivamente: L-283 - sem crítica, L-291 - sem crítica, L-286, 
L-396 - sem crítica, L-493 - críticas de Sinzig e de Frei Valdomiro Chatas, ofm, e L-511 crítica de Sinzig. Há ainda o $3^{\circ}$ Responsório das Matinas de Natal, aprovado com o código L-212, mas também sem crítica (CAMS-RJ, 1946a).

\section{REFERÊNCIAS}

AZEVEDO, Luís Heitor Corrêa de. o Espírito Religioso na Obra de José Maurício. Música Sacra, Petrópolis, a.6, n.5, p. 85-94, 1946.

BOURDIEU, Pierre. A economia das trocas simbólicas. São Paulo: Perspectiva, 1992.

BUCKLEY, Walter. A sociologia e a moderna teoria dos sistemas. São Paulo: EdUSP, [1971].

CAMS-RJ - Comissão Arquidiocesana de Música sacra do Rio de Janeiro. $1^{\circ}$ Índice das Músicas Examinadas para uso litúrgico pela Comissão Arquidiocesana de Música Sacra do Rio de Janeiro. Petrópolis: Vozes, 1946a.

- Livro de Ouro da Música Sacra. Música

Sacra, Petrópolis, a.4, n.8, p. 157-160, 1944a. - Livro de Ouro da Música Sacra. Música Sacra, Petrópolis, a.4. n.11, p. 217-220, 1944b. Não servem para a Igreja. Música Sacra, Petrópolis, a.6, n.1, p. 19-20, 1946b.

CANDAU, Joël. Memória e identidade. São Paulo: Contexto, 2011.

CASTAGNA, Paulo. Avanços e perspectivas na Musicologia Histórica Brasileira. Revista do Conservatório de música da UFPel, Pelotas, v.1, n.1, p. 32-57, 2008.

- Estilo Antigo na prática musical religiosa paulista e mineira dos séculos XVIII e XIX. Tese (Doutorado em História). 2000. Faculdade de Filosofia, Letras e Ciências Humanas, Universidade de São Paulo.

CNBB - Conferência Nacional dos Bispos do Brasil. A música litúrgica no Brasil. 1976. Disponível em: <http://www.cnbb.org.br/ component/docman/doc_download/340-amusica-liturgica-no-brasil-estudo-cnbb-79>. Acesso em: 12 abr. 2015.

Pastoral da música litúrgica no Brasil.

1998. Disponível em: <http://www.cnbb.org. $\mathrm{br} /$ publicacoes/documentos-para-downloads/ doc_view/339>. Acesso em: 12 abr. 2015.

COUTINHO, Afrânio (Org.). Era Romântica. v.3. 7.ed. São Paulo: Global, 2004.

DUARTE, Fernando Lacerda Simões. Do canto religioso popular à música autóctone: memórias, esquecimentos e o desenvolvimento de uma identidade musical local no catolicismo pós-conciliar. In: SIMPósIO BRASILEIRO DE PÓS-GRAdUANDOS EM MÚSICA, 3., 2014, Rio de Janeiro. Anais; Rio de Janeiro: Unirio, 2014.

Resgates e abandonos do passado na prática musical litúrgica católica no Brasil entre os pontificados de Pio X e Bento XVI (19032013). São Paulo, 2016. 495 f. Tese (Doutorado em Música) - Instituto de Artes, UNESP, São Paulo, 2016.

DUFFY, Eamon. Santos e pecadores: história dos papas. São Paulo: Cosac \& Naify, 1998.

ELIAS, Norbert. 0 processo civilizador: Uma história dos costumes. Rio de Janeiro: Jorge Zahar, 1994.

FOLLIS, Fransergio. Modernização urbana na Belle Époque paulista. São Paulo: EdUNESP, 2004.

FORTESCuE, Adrian. The Mass: A Study of Roman Liturgy. Londres: Longmans, Green and Co., 1914.

GARCIA, José Maurício Nunes. Missa em si bemol. Partitura manuscrita. Parte de $2^{\circ}$ violino. Recolhida ao Arquivo Público do Maranhão (São Luís, Maranhão, Brasil), Coleção João Mohana, n.2102/95, [19--]a.

. Missa em si bemol. Partitura manuscrita. Canto e harmônio. Recolhida ao Arquivo Público do Maranhão (São Luís, Maranhão, Brasil), Coleção João Mohana, n.2102/95. [19--]b.

GODINHO, Josinéia. Do Iluminismo ao Cecilianismo: A música mineira para missa nos séculos XVIII e XIX. Belo Horizonte, 2008. Dissertação (Mestrado em Música) - Escola de Música, Universidade Federal de Minas Gerais, 2008.

GOLDBERG, Luiz Guilherme. Alberto Nepomuceno 
e a Missa de Santa Cecília de José Maurício Nunes Garcia. In: CASTAGNA, Paulo (Org.). ENCONTRO DE MUSICOLOGIA HISTÓRICA: Perspectivas metodológicas no estudo do patrimônio arquivístico-musical Brasileiro, 6., 2004, Juiz de Fora. Anais... Juiz de Fora: Centro Cultural PróMúsica, 2006. p.138-173.

HAZAN, Marcelo Campos. Raça, Nação e José Maurício Nunes Garcia. Resonancias, Santiago de Chile, v.24, n.1, p. 23-40, 2009.

- acervo musical do Arquivo do Cabido Metropolitano do Rio de Janeiro. [20 - ]. Disponível em: <http://acmerj.com.br/CMRJ_ HIST.htm>. Acesso em: 10 jun. 2014.

IGAYARA, Susana Cecília. Henrique Oswald (1852-1931): A Missa de Réquiem no conjunto de sua música sacra coral. São Paulo, 2001. Dissertação (Mestrado em Música) - Escola de Comunicação e Artes, Universidade de São Paulo, 2001.

LE GOFF, Jacques. História e memória. Campinas: Editora da UNICAMP, 1990.

LESSER, Jeffrey. A invenção da brasilidade: identidade nacional, etnicidade e políticas de imigração. São Paulo: Editora UNESP, 2015.

LUHMANN, Niklas. Social Systems. Stanford, CA: Stanford University Press, 1995.

MARCO, Tomás. Spanish Music in the Twentieth Century. Harvard: Harvard College, 1993.

MONTERO, Paula. Tradição e modernidade: João Paulo II e o problema da cultura. Revista Brasileira de Ciências Sociais, Rio de Janeiro, a.7, n.20, p.90-112, 1992.

MOREIRA, Gabriel Ferrão. 0 uso da temática indígena na música de concerto latinoamericana: casos do Brasil, Peru, México e Bolívia. Opus, Belo Horizonte, v.22, n.1, p. 179201, 2016.

NORA, Pierre. Entre a memória e a história: a problemática dos lugares. Projeto História, São Paulo, n.10, p.7-28, 1993.

SANTOS, Tânia Cristina Franco et al. A memória, - controle das lembranças e a pesquisa em história da enfermagem. Escola Anna Nery:
Revista de Enfermagem, v. 15, n.3, p. 616-625, 2011.

SCHUBERT, Monsenhor Guilherme. Música sacra no Rio de Janeiro em redor de 1910. In: COSTA, Luiz Antônio Severo da et al. Brasil 1900-1910. v.2. Rio de Janeiro: Biblioteca Nacional, 1980.

SOBRE M:SICA SACRA. Motu proprio Tra le Sollecitudini. 1903. Disponível em: <http:// www.vatican.va/holy_father/pius_x/ motu_proprio/documents/hf_p-x_motuproprio_19031122_sollecitudini_po.html >. Acesso em: 10 jan. 2010.

SOUZA, José Geraldo de. Folcmúsica e liturgia: subsídios para o estudo do problema. Petrópolis: Vozes, 1966.

VERMES, Mônica. Alguns aspectos da música sacra no Rio de Janeiro no final do século XIX. Revista Eletrônica de Musicologia - REM, Curitiba, v.5, n. 1, 2000. Disponível em: <http:// www.rem.ufpr.br/_REM/REMv5.1/vol5-1/rio. htm>. Acesso em: 20 set. 2010.

VILELA, Ivan. Nada Ficou Como Antes. Revista USP, São Paulo, n.87, 14-27, 2010.

VERnet, Augustin. A Igreja Paulista no Século XIX: a reforma de D. Antônio Joaquim de Melo (1851-1861). São Paulo: Ática, 1987.

\section{SOBRE O AUTOR}

Fernando Lacerda Simões Duarte é graduado em Direito (Universidade Presbiteriana Mackenzie, 2006), em Música com habilitação em Composição e Regência (UNESP, 2008), mestre em Música - Musicologia (UNESP, 2011) e doutor em Música, na área de concentração Música: Relações Interdisciplinares (UNESP, 2016). Orientou monografias de conclusão de curso e desenvolveu atividade docente nos níveis técnico-profissionalizante, superior (UFS, 2011; FAMOSP, 2012), de especialização (FPA, 2013) e pós-graduação stricto sensu - mestrado e doutorado (PPG-Música/UFMG, 2017; PPGArtes/UFPA, 2017-2018). Tem experiência na área de Música, sobretudo nas temáticas das práticas musicais religiosas católicas e acervos musicais brasileiros. Sua pesquisa por acervos alcança cerca de cem cidades brasileiras. Autor 
de um livro e aproximadamente oitenta títulos entre artigos e trabalhos completos em anais, publicados ou em processo de publicação. Foi segundo secretário da Associação Nacional de Pesquisa e Pós-Graduação em Música na gestão 2015-2017. Realizou estágio pósdoutoral junto ao Programa de Pós-Graduação em Música da Universidade Federal de Minas Gerais e atualmente estagia junto ao Programa de Pós-Graduação em Artes da Universidade Federal do Pará, ambos com com bolsa CAPES/ $P N P D$. Pesquisador junto a sete grupos de pesquisa brasileiros. 